СД-45.

\title{
ОПРЕДЕЛЕНИЕ СЕРНИСТОГО ИПРИТА, РЕГЕНЕРИРОВАННОГО ИЗ СОСТАВА АДДУКТОВ С БЕЛКАМИ ПЛАЗМЫ КРОВИ, МЕТОДОМ ГХ-МС/МС
}

Шачнева М.Д., Корягина Н.Л., Савельева Е.И.

ФГУП «НИИ ГПЭЧ» ФМБА России, г.П. Кузьмоловский, Россия shachneva_mariya@mail.ru

DOI: 10.26902/ASFE-11_138

Установление факта возможного применения химического оружия осуществляется на основании результатов анализа проб окружающей среды и биопроб человека или животных, находившихся в зоне инцидента. Сернистый иприт - отравляющее вещество кожно-нарывного действия, обладающее сильными электрофильными свойствами. Основными мишенями действия иприта являются биомолекулы крови (альбумин, гемоглобин, ДНК и др.).

Целью настоящей работы являлась разработка методики количественного определения сернистого иприта, регенерированного из состава белковых аддуктов, а также исследование стабильности образцов плазмы крови, экспонированных ипритом, при различных условиях хранения.

Объектами исследования были образцы плазмы крови с концентрациями от 0.5 до 100 нг/мл по внесенному иприту. Процедура пробоподготовки включала обработку концентрированной соляной кислотой белка, выделенного из 0.5 мл плазмы крови, внесение в гидролизат внутреннего стандарта (нафталина- $\mathrm{D}_{8}$ ), экстракцию регенерированного иприта и внутреннего стандарта гексаном с последующим анализом методом газовой хроматографии с тандемным масс-селективным детектированием в режиме ионизации электронами (ГХМС/МС-ИЭ). Линейный диапазон определяемых концентраций составил 1-100 нг/мл, предел детектирования и предел количественного определения по внесенному в плазму крови иприту были установлены на уровне 0.5 нг/мл и 1 нг/мл, соответственно.

Исследована стабильность аддуктов иприта с белками плазмы крови при хранении проб в холодильной камере при $4{ }^{\circ} \mathrm{C}$ и в термостате при $30{ }^{\circ} \mathrm{C}$ в течение 35 дней после приготовления. Показана возможность определения, регенерированного из белковых аддуктов иприта в образцах плазмы крови с внесением иприта в концентрации 2 нг/мл в течение 3-х недель независимо от условий хранения, при этом содержание определяемого соединения снизилось на 60 \%. Образцы плазмы крови с концентрациями 5, 20 и 50 нг/мл по внесенному иприту были пригодными для анализа в течение как минимум 35 дней после приготовления, при этом содержание аналита в пробах снизилось на 30 \% (хранение при $4{ }^{\circ} \mathrm{C}$ ) и $70 \%$ (хранение при $\left.30{ }^{\circ} \mathrm{C}\right)$.

В проведенных исследованиях продемонстрирована возможность определения иприта, регенерированного из состава белковых аддуктов, в образцах плазмы крови после длительного хранения в разных температурных условиях. Это актуально для анализа биопроб, отобранных у пострадавших в результате чрезвычайных ситуаций, т.к. поддержание холодовой цепи по всему циклу от отбора биопробы до доставки ее в стационарную лабораторию является трудновыполнимой, а иногда и нерешаемой задачей.

Разработанная методика была применена лабораторией аналитической токсикологии ФГУП «НИИ ГПЭЧ» ФМБА России для разработки сценария 6-го международного квалификационного теста ОЗХО по анализу биомедицинских проб, а также для контроля стабильности биообразцов, разосланных лабораториям-участникам. 